\title{
PLATÃO E A POESIA NA REPÚBLICA*
}

\author{
Maria da Penha Villela-Petit**
}

RESUMO Platão não é o iniciador, e sim o herdeiro da "velha divergência" entre filósofos e poetas. A motivação ético-teológica, que já animava Xenófanes, vai se reatualizar na República. Para poder apreciar o sentido dessa reatualização, importa que não se considere o Livro $X$ isoladamente, mas se atente para os primeiros livros do diálogo. Neles, e com vistas a uma melhor determinação do justo - que é o que está em pauta-, Platão mostra a necessidade de se discutir as afirmações dos poetas. Trata-se assim de destituí-los da autoridade de que ainda gozam na educação e na opinião comum. Só graças à discussão filosófica e a uma educação por ela inspirada - o que pressupõe a produção ou a seleção de mitos-é que se pode esperar uma maior realização da justiça, tanto no plano do indivíduo (do governo de sua alma) quanto no nível da cidade. A leitura aqui proposta das "razões" de Platão na República não impede que reconheçamos a importância da tragédia para a compreensão da existência humana, inclusive no que toca à idéia do divino.

Palavras-chave: Platão, República, poesia, mito, religião, educação.

ABSTRACT Plato is not the initiator, but rather the heir of the "old quarrel", between philosophers and poets. The ethical and theological motivation that drove Xenophanes is brought to date in the Republic. In order to realize that, one must take into account the whole of the dialogue - where the definition of justice is at stake - and, more precisely, its first books.

* Texto recebido em abril e aprovado em maio de 2003. Ele reproduz uma conferência apresentada em 20 de agosto de 2002 na UFMG.

** Pesquisadora do CNRS, «Archives Husserl» (Paris, França), e Professora de Estética do Institut Catholique de Paris. 
There, Plato shows how important it is to put the poets' claims to question. The point is, after all, to deprive them of the authority they enjoy in what concerns educational matters as well as with public opinion. It is only through an education which is inspired by philosophical questioning - which also implies the production and selection of myths - that one can expect more justice both on the individual (the gouvernment of his soul) and on the city levels. The reading we propose of Plato's "reasons" in the Republic does not keep us from recognizing the part tragedy plays in a better understanding of human existence, including the idea of the divine.

Key words: Plato, Republic, poetry, myth, religion, education.

\section{A "velha divergência" entre filosofia e poesia}

Como compreender a alusão do Livro X da República à velha divergência (palaià diaphorá) entre poesia e filosofia? Convém não esquecermos que, em seus primórdios, boa parte do que virá a ser chamado de filosofia fora enunciado em poemas. A divergência a que se refere Platão não tem pois a ver com o fato de o pensamento ser enunciado em versos, ou seja, sob uma forma poemática, embora, para ele, essa não possa ser mais o modo de exposição do filosofar, por não ser congruente com a prática do dialégesthai ${ }^{1}$ que, a partir de Sócrates, passou a caracterizar o pensamento filosófico.

A bem dizer, ao falar de poesia, Platão não está se referindo a tudo aquilo que se apresenta como poema. "Poesia" no contexto da República tem a ver com as composições dos grandes poetas da tradição, e, sobretudo, com a poesia mimética, seja ela épica ou trágica. Antecipa-se de certo modo aqui o que será explicitamente enunciado na Poética de Aristóteles, isto é, que nem tudo o que é exposto em verso deve ser considerado como poesia. O fato de escrever em versos não basta para definir o "poeta".

"Costuma-se — diz Aristóteles— chamar assim aqueles que expõem em metros um assunto de medecina ou de história natural; e no entanto Homero e a Empédocles não têm nada em comum senão o metro, e por conseguinte é legítimo chamar um de poeta e o outro de pensador da phúsis (fisiólogo), de preferência a poeta"2. Em suma, na Poética a denominação de poesia fica de

1 Sobre o dialégesthai em Platão, ver DIXSAUT, Monique, Métamorphoses de la dialectique dans les dialogues de Platon, Vrin 2001.

2 Aristóteles, Poética 1447 b 16-19. Edição usada: DUPONT-ROC, Roselyne e LALLOT, Jean (texte, traduction et notes par), Aristote. La Poétique, Éditons du Seuil, Paris 1980. 
certo modo reservada às obras de caráter mimético, como as de Homero e as dos poetas trágicos ou cômicos ${ }^{3}$.

Sabemos, no entanto, que, relativamente a Empédocles, a distinção estabelecida por Aristóteles não foi respeitada pelos Antigos. Em sua Ars Poetica, por exemplo, Horácio não hesita em chamar de poeta o pensador da Sicília.

$\mathrm{Na}$ verdade, a designação do poeta como poietés só aparece no séc. $\mathrm{V}$ a.C. Até então Homero e seus companheiros eram designados como cantadores, aedos (aoidoí), isto é, aqueles que cantam os altos feitos dos homens e dos deuses. Por ele conferir o kléos, a fama imperecível aos heróis, Homero poderia até receber como alcunha Phémios (de phéme) ${ }^{4}$, que foi o nome dado ao aedo da Odisséia. Ademais, os que haveriam de ser chamados ulteriormente de poetas eram freqüentemente qualificados de sophoí. E é, como tal, que haveriam de ser tidos como concorrentes dos philósophoi. Disso testemunha, ironicamente, Sócrates no Íon de Platão ${ }^{5}$.

Cabe ainda observar que uma das primeiras ocorrências de poietés se dá em Heródoto $(2,53)$, justamente numa passagem onde se trata de Homero e de Hesíodo como aqueles que em seus versos fundaram a teogonia e traçaram a figura dos deuses.

Por outro lado, quando mencionamos o fato de que em sua origem boa parte do pensamento "filosófico" ou "pré-filosófico" fora formulado em poemas, o nome que primeiro nos ocorre é o de Parmênides. Mas já Xenófanes, originário de Cólofon, cidade iônica, que emigrara para a Grande Grécia, onde Parmênides teria sido seu discípulo ${ }^{6}$, se exprimira também em poemas, como sói acontecer com os portadores de palavras essenciais numa comunidade onde predomina a tradição oral.

Segundo Diógenes Laércio, Xenófanes "escreveu versos épicos, elegias e jambos contra Hesíodo e Homero e se fez censor de suas afirmações sobre os deuses" (IX, 18)

O caso de Xenófanes nos interessa particularmente, pois que, embora adotasse a forma tradicional versificada enunciando seu pensamento em poemas, ele não se privava de criticar os grandes poetas da tradição: Homero e Hesíodo. Conta ainda Diógenes Laércio (ibidem) que Timão louvara Xenófanes nos seguintes termos:

3 O que não exclui que tivesse também levado em conta a poesia lírica em seus outros livros que não nos foram transmitidos.

4 Sobre phéme em Platão, ver BRISSON, Luc, Platon, les mots et les mythes, François Maspero, Paris 1982, em particular p. 39-45.

5 Cf. Platão, íon 532D. Edição usada: MÉRIDIER, Louis (texte établi et traduit par), Platon. CEuvres complètes, t. V, p. I, Les Belles Lettres, Paris 1978.

6 Veja-se a menção que a isso faz Aristóteles, Met. A 5 986, b, 18.

7 Em DUMONT, Jean-Paul (édition établie par), Les Présocratiques, Pléiade, Gallimard, Paris 1988. 
"Xenófanes, um espírito modesto e censor das mentiras forjadas pela gente homérica".

Esses versos atribuídos a Timão são também reproduzidos por Sexto Empírico, mas com o seguinte acréscimo:

"De Deus ele compôs uma imagem mais pura que nada deve ao homem : um Deus em toda parte igual <imóvel>, de um só bloco e dotado de um intelecto bem mais inteligente que todo pensamento" (Hyp. Pirrh. I 225) .

Encontramos ainda em Sexto Empírico duas versões de versos atribuídos a Xenófanes, onde podemos ler:

"Os deuses são acusados por Homero e Hesíodo de tudo o que entre nós é vergonhoso e repreensível vemo-los cometer roubo, adultério e empregar entre eles a mentira".

Foi essa postura crítica de Xenófanes diante da tradição que levou G.S. Kirk e J.E. Raven a escreverem: "He was a poet with thoughtful interests, especially about religion and the gods, which led him to react against the archetype of poets and the mainstay of contemporary education, Homer" ${ }^{9}$.

Recentemente publicado, um estudo muito instrutivo sobre Xenófanes o focaliza sob esse ângulo da teologia e da teodicéia ${ }^{10}$. Seu autor, Emese Mogyoródi, aponta justamente semelhanças entre a preocupação de Xenófanes com a crise ético-religiosa e a que se manifestará mais tarde em Platão, do qual nesse sentido ele seria um precursor ${ }^{11}$.

Também em Heráclito nos deparamos com uma crítica feroz a Homero e a outros poetas. Lemos, por exemplo, em Diógenes Laércio que o filósofo de Éfeso costumava dizer que "Homero merecia ser afastado dos concursos a pauladas, como também Arquíloco"12.

8 Em DUMONT [1988].

9 KIRK, G.S. e RAVEN, J.E., The Presocratics Philosophers, Cambridge University Press, 1977 [1963], p.167.

10 Cf. MOGYORODI, Emese «Xenophanes as a philosopher : theology and theodicy», em LAKS, André e LOUGUET, Claire (éd. par), Qu'est-ce que la philosophie présocratique?-What is presocratic philosophy ?, Septentrion, Presses Universitaires, Lille 2002, p. 253- 286.

11 Mogyoródi [2002] (p. 284) escreve: «Xenophanes reflected upon the religious-moral crisis and challenges of his time and with remarkable intellectual freedom, valour and consistency redefined the divine in a way that seemed to him to comply both with piety and the demands of a new moral sensitivity. In that attempt he was a precursor of no smaller a philosopher than Plato".

12 Héraclite, frag. 42, em Diógenes Laércio IX, I. Ver também em BOLLACK, Jean, e WISMAN, Heinz, Héraclite ou la séparation, Editions de Minuit, Paris 1972, p.159. 
Tem-se aí a evidência de que na atitude dos primeiros pensadores em relação a Homero e Hesíodo o que estava primeiramente em causa é o mesmo que virá também à baila nas críticas de Platão : a imagem que apresentavam dos deuses.

Como notaram vários comentadores e tradutores da República (penso em Émile Chambry ${ }^{13}$ ), bem como Hans-George Gadamer em sua conferência, feita em 1934, "Platão e os poetas" ${ }^{14}$, a crítica aos poetas não era nenhuma novidade. Daí a expressão de "velha divergência (ou disputa)" utilizada por Platão. Verifica-se ao mesmo tempo o quanto é errôneo lhe atribuir a origem da crítica aos poetas. E, no entanto, é o que de amiúde fazem os adversários de Platão — ou melhor, de um Platão caricatural—, com o intuito de acusá-lo, seja de algum imperdoável pendor contra a liberdade de pensamento no sentido moderno (Karl Popper), seja de um fatal desvio de onde resultou o começo do pensamento metafísico que virou as costas à grandeza do primeiro pensamento grego e do qual a crítica à "poesia" seria seguramente um sintoma. (Refiro-me aqui à interpretação de Heidegger muito marcada pelas acusações de Nietzsche ${ }^{15}$.)

Para apreciarmos a posição de Platão, é bom nos tornarmos mais atentos, graças à experiência dos antropólogos, ao que representa a palavra dos poetas dentro de uma sociedade onde prevalece a tradição oral. Não se constitui ela como a referência imprescindível enquanto depositária dos valores e ensinamentos éticos? A palavra dos poetas tinha então tudo a ver com a paideía, isto é, com a educação em sentido lato e, portanto, com a formação do êthos. Os poetas eram verdadeiramente os mestres, os educadores da Grécia, como se dizia sobretudo de Homero. E foi disso que souberam se servir os sofistas.

Sem tal situação em mente como ponderar a crítica que, em sua busca de uma verdade mais elevada, os primeiros pensadores dirigiram aos poetas, e ainda mais a posição assumida por Platão em sua luta contra a corrupção do êthos do indivíduo e da polis, agravada pelos ensinamentos dos sofistas?

No horizonte dessas considerações é que abordamos um diálogo como a

13 CHAMBRY, Émile (texte établi et traduit par), Platon. CEuvres, t. VII, 3 vol., Les Belles Lettres, Paris 1975.

14 Cf. GADAMER, Hans-George, «Plato und die Dichter», em Gesammelte Werke 5, Griechische Philosophie I, J.C.B. Mohr, Tübingen 1985, p. 190.

$15 \mathrm{Na}$ Genealogia da Moral, por exemplo, Nietzsche declara com grande veemência: «...Platão, o maior inimigo da arte que a Europa jamais conheceu. Platão contra Homero: eis o verdadeiro, o total antagonismo — de um lado, o caluniador da vida, de outro, aquele que só podia ser seu adorador, a natureza de ouro" - NIETZSCHE, Friedrich, La Généalogie de la Morale, em CEuvres complètes, vol. VII, trad. fr. par Isabelle Hildebrand et Jean Gratientextes et variantes établis par Giorgi Colli et Massimo Montinari, Gallimard, Paris 1971. No entanto, não se pode passar sob silêncio a ambivalência da posição de Nietzsche relativamente a Platão. Cf. DIXSAUT, Monique, «De Platon vers Nietzsche: l'autre manière de philosopher», Bulletin de la Société Française de Philosophie, séance du 23 janvier 1999, avril-juin (1999). 
República (Politeía), que é um diálogo sobre a justiça, como estão a indicar os subtítulos recebidos da tradição, e perì dikaíou, politikós. Se a questão da justiça e do governo justo é mesmo o que o diálogo se propõe a discutir, talvez caiba ainda perguntar: mas o governo propriamente de quê? Não somente o da cidade, da pólis, como parece óbvio, mas, antes de tudo, o governo da alma, o governo de si próprio. A vida individual sendo inseparável da vida da cidade, da vida pública, como bem sublinhou Ernst Cassirer ${ }^{16}$ em defesa de Platão.

\section{A discussão em torno das afirmações dos poetas nos primeiros livros do diálogo}

É deveras significativo que ao se iniciar a interrogação sobre a justiça o pensamento veiculado pelos poetas tenha que ser reiteradamente evocado, como vemos nos primeiros livros da República, e que a questão da poesia ressurja ainda no último livro. Este, quase sempre, é o único em vista quando se menciona a posição crítica de Platão relativamente aos poetas. Mas levar tão em conta somente o Livro X, excluindo os primeiros, é comprometer a interpretação do diálogo. Não há então como situar a verdadeira posição de Platão em relação à poesia, que é bem mais complexa do que sugere o famoso tópico da expulsão dos poetas.

Vejamos pois a República na ordem em que se apresenta. No primeiro Livro, Platão esboça as circunstâncias do diálogo. Sócrates se encontra no Pireu onde fora participar de uma festa religiosa em honra de Ártemis. Cumpridas as obrigações rituais e pronto para retornar a Atenas, cede contudo ao pedido dos jovens e vai à casa de Céfalo, o rico pai de um deles, que lhe oferece hospitalidade. O religioso constitui assim o pano de fundo do diálogo. Isto prepara o leitor para não estranhar que já de saída a questão do divino venha à tona. Além do mais a abertura da conversa entre Sócrates e seus anfitriões é jocosamente entremeada de expressões ou fórmulas feitas e recorrentes na poesia. De Céfalo, o dono da casa, diz-se que devido à idade ele já não podia percorrer, "com pé leve" o caminho até Atenas.

Desde o começo, fica patente que Platão entende confrontar o saber tradicional forjado pelas palavras dos poetas com o pensamento dialético, que se esforça não em repetir, por ouvir dizer, como as coisas se passaram ou se passam, mas em determinar melhor as coisas de que se fala. Que tal confronto esteja de saída em pauta as primeiras trocas entre Céfalo e Sócrates o confirmam. Ao contrário do que ocorre com tantos dos seus amigos, Céfalo 
diz aceitar plenamente e sem queixas a velhice. E o faz contentando-se em repetir com a maior admiração e louvor as palavras ouvidas de Sófocles que, solicitado a se pronunciar sobre as desvantagens da idade avançada, havia replicado :

"Nem me fale amigo, estou encantado de ter escapado ao amor, como se tivesse escapado das mãos de um senhor furioso e selvagem" (Resp. 329 C).

Ora se Sócrates aquiesce a Céfalo quando este afirma que a maneira como a velhice é vivida depende do caráter dos homens, talvez não aprove senão da boca para fora as palavras de Sófocles no que diz respeito ao amor. Por quê? Porque elas traem um pensamento que reduz o amor exclusivamente ao carnal. Tal concepção não faz justiça a Eros. Basta pensar no ensino do Banquete sobre a relação que une a beleza ao amor para que se compreenda o quanto a declaração de Sófocles não podia ser assim tão grata aos ouvidos de Sócrates.

É fazendo, em seguida, referência à fortuna de Céfalo — que seus amigos têm como fator decisivo de sua aceitação sem queixumes da velhiceque Sócrates relança a conversa sobre o tema central do diálogo : a justiça.

Durante o pouco tempo em que Sócrates conversa com o dono da casa, que não vai tardar a se retirar, vê-se que este é incapaz de pensar por conta própria. Céfalo contenta-se em reproduzir as frases dos poetas que sabe de cor e que entram em sintonia com suas disposições do momento. Platão caracteriza assim de maneira magistral a cultura de seus contemporâneos, dando a ver em que consiste o pensamento do vulgo, dos que não pensam, e como os oportunistas, os demagogos (hoje diríamos os especialistas em comunicação) podem disso se servir. Em sua época, essa cultura ou esse saber repousava em grande parte sobre as palavras dos poetas, que gozavam de um imenso prestígio e que eram freqüentemente utilizadas para nortear a vida e a ação política.

Que, por toda sorte de razões, inclusive pelo advento dessa outra forma de pensamento que deu origem à filosofia, o saber tradicional estivesse em crise, é o que sobressai também quando Sócrates tenta mostrar a insuficiência da concepção da justiça defendida por Simônides. Concepção segundo a qual "é justo restituir a cada um aquilo que se lhe deve" (Resp. $331 \mathrm{E})$ e que o justo é "fazer o bem a seus amigos" e o "mal a seus inimigos" (Resp. 332 D).

Antes de mais nada, o propósito de Sócrates é levar os jovens a ver que não devem admitir as palavras que lhes são transmitidas ${ }^{17}$ sem submetê-las a 
exame e buscar apreciá-las em função da pertinência (ou não) do que nelas se diz. Já nessa primeira cena, em que se constitui o Livro I, Platão evoca Homero de modo irônico pintando a confusão que se apodera do espírito de Polemarco quando este, não sabendo mais o que pensar, conclui, sem renegar o poeta, que, em todo caso, ele, Polemarco, "acredita que a justiça consiste em servir seus amigos e prejudicar seus inimigos" (Resp. 334 B).

Insatisfeitos com o rumo tomado pela conversa, os ouvintes mais exigentes vão obrigar Sócrates a encetar uma discussão sobre bases mais sólidas a fim de que a verdadeira natureza da justiça e da injustiça e os efeitos que cada uma produz sobre a alma acabem se manifestando com clareza (358 B). Sem rodeios Glauco declara que jamais ouviu uma pessoa "defender de maneira satisfatória o partido da justiça e a superioridade dela sobre a injustiça" (358 C-D). Com essa declaração traça ele o programa que espera ver realizado por Sócrates e convida então este último a empregar o máximo de seu poder de refutação em favor da tese de que a justiça é infinitamente superior à injustiça.

Temos aí um ensino sobre qual deve ser a maneira de proceder do filósofo : expor as teses em jogo no seu máximo vigor e questioná-las com vistas a determinar melhor a falha que nelas se esconde e, portanto, sua possível inadequação ao que pode ser intuído pelo intelecto voltado para a verdade. Sobre esses traços do método socrático falou aliás muito bem um poeta, Paul Claudel. Após ter lido Poésie Pure e Prière et Poésie do abade Brémond, que foi um importante crítico literário, Claudel lhe escreve uma carta elogiando seus textos nos seguintes termos:

"São obras verdadeiramente socráticas que têm por matéria menos as respostas do
que as questões, mas questões bem colocadas das quais é impossível se desfazer por
escapatórias. Ninguém gosta de ser questionado de uma maneira tão rigorosa e tão
indiscreta e o embaraço irritado das pessoas de quem o senhor abala o preconceito
se explica do mesmo modo que o dos interlocutores daquele velho perseguidor de
almas"18.

Mas o filosofar em Platão também pressupõe a visão, uma visão mais alta e liberada dos enganos entretidos pela vida em comum. Ela requer a saída da caverna, da caverna das aparências, como se verá mais adiante no diálogo. No prolongamento destas considerações, encaremos agora alguns aspectos do Livro II, que procura justamente mostrar a variedade de procedimentos à disposição daquele que questiona ou se questiona. Glauco, que 
passou a ser o interlocutor de Sócrates, pede que se examine a oposição justiça/injustiça. E, para pôr à prova a capacidade dialética de Sócrates, propõe defender a tese de que "não se pratica a justiça senão forçado e por falta de poder cometer a injustiça" (359 B). Para ilustrar esta afirmação, conta a fábula do anel de Giges. Tal fábula é uma espécie de variação imaginativa, no sentido husserliano, sobre a oposição entre, por um lado, ser justo e, por outro, aparecer como justo, mesmo sendo injusto. Nela encontramos a famosa contraposição entre o personagem da fábula e a do homem justo que, despojado de tudo, persevera na justiça ainda que ao preço da própria vida (361B-D).

Ora, é fazendo apelo a Ésquilo que Platão apresenta o personagem do justo.

"Coloquemos, sugere ele, diante de nós pela imaginação o homem justo que, como diz Ésquilo, quer não aparecer mas ser um homem de bem” (361 B).

Verifica-se por aí que a oposição entre ser e aparecer que, em sua Introdução à Metafísica ${ }^{19}$, Heidegger afirma ser característica desta última, imputando-a a Platão, vem de muito mais longe. Nasce da observação perspicaz da conduta humana e transcende tanto as fronteiras culturais quanto as delimitações do que Heidegger chama de "metafísica", tanto mais que já havia sido focalizada pelos poetas.

Vemos outrossim que Platão não renega sistematicamente o que os poetas afirmam. Necessário é o discernimento relativo às afirmações que fazem em suas obras. Platão não hesita em recorrer aos poetas quando o que dizem se aproxima da verdade que a filosofia tem por bem buscar. Além do mais, faz freqüentemente apelo a analogias tomados do campo artístico. É assim que, no nosso diálogo, Sócrates se serve da analogia com o trabalho do artista a fim de louvar Glauco, já que este, como o faria um bom escultor, esboçara com grande arte a imagem de dois tipos de homem : a do justo e a do injusto.

Voltando a Ésquilo convém que nos detenhamos sobre a nota de Emile Chambry, o tradutor para o francês da República, na edição Les Belles Lettres.

"Platão expulsa os poetas da República, mas ele se nutriu de Homero, de Hesíodo, de Píndaro, de Simônides e dos três grandes trágicos. Toma-lhes emprestado muitos traços que inclui no seu raciocínio como pérolas cheias de brilho. É um dos seus meios favoritos para introduzir variedade e prazer nos seus desdobramentos. Tem la Métaphysique, trad. fr. de Gilbert Khan, PUF, Paris 1958. 
em particular por Ésquilo a mesma veneração que Aristófanes e como este último não poupa Eurípides dos seus sarcasmos" ${ }^{\text {"20 }}$.

Essa observação tanto tem de embaraçosa quanto de significativa. Como pode Platão admirar tanto Ésquilo e expulsar os poetas da cidade ? Não haveria já neste paradoxo indicação suficiente para reconhecermos a necessidade de se encarar de modo mais circunspecto a questão da expulsão dos poetas, fonte de tantas aberrações e anacronismos na interpretação do pensamento do autor da República?

Deixemos por enquanto essa questão de lado para primeiramente evocarmos um aspecto da peça Os Sete contra Tebas de Ésquilo.

Inimigo de Tebas, a cidade de seus pais, Polinices fez gravar em seu escudo "um guerreiro em ouro sendo conduzido por uma mulher, guia de fronte serena, que aparece como representando a justiça". Junto à figura lê-se a inscrição: "Eu conduzirei este homem para que ele recupere sua cidade e o acesso à casa paterna" (v. 642-648).

Da parte de Polinices isto constitui uma afronta e um sacrilégio. Preparando-se para destruir seu país, ele não hesita em se apropriar do emblema da justiça (Díke). Mas sua invocação a Díke, filha virgem de Zeus, é temerária e trai a contradição na qual se encontra. Nem em seus atos nem em sua alma Polinício honrou a Justiça. Essa insolência leva por sua vez Etéocles a perder a cabeça.

A peça de Ésquilo girava assim em torno da justiça que é precisamente a questão do diálogo. O que espanta é que muitos dos comentadores da República não tenham dado mais atenção ao poema trágico, tanto mais que Platão não se priva de adotar as palavras do vidente Anfiaraos.

Examinemos agora alguns dos argumentos apresentados por Adimanto, que substitui Glauco no diálogo com Sócrates. Ele propõe defender a tese de que a justiça é preferível à injustiça pelo que traz de recompensas da parte dos deuses e de vantagens juntos aos homens. Para ilustrá-la, faz apelo a dizeres, para lá de ingênuos, "do bom Hesíodo e de Homero". Hesíodo, por exemplo, afirmara que em favor dos justos "os deuses faziam que os carvalhos se carregassem de frutos no seu topo e de abelhas no seu tronco", ou ainda que "para eles as ovelhas se cobriam de espessos mantos de lã" (Resp. 363 B-C). A consideração de Homero na Odisséia não fica atrás, pois reza que "os frutos da terra e a prolífica abundância dos animais são presentes dos deuses aos homens que os temem e perseveram no bom caminho" (363 C).

Esse providencialismo primário já tinha sido ultrapassado por Ésquilo, 
quando observa, por exemplo, "que o anzol divino não distingue entre os justos e os injustos". Apoiando-se agora em Hesíodo, Adimanto vai então defender a tese que "o caminho da injustiça é liso, enquanto o da justiça é árduo, pois, diante da virtude, os deuses colocaram muito suor». Invoca também Homero para quem "os deuses se deixam dobrar pelas oferendas, mesmo daqueles que transgridem os princípios e cometem faltas" (Resp. 364 D-E)

Todas essas evocações de Platão visam a tornar patente o quanto a fala dos poetas é cheia de deturpações e de inconseqüências. Por que razões, apesar do prazer que sua poesia nos proporciona, não submeter seus dizeres a questionamento? Podem eles servir de esteio e de referência na educação dos jovens? Que cidade é aquela que adota tais mestres por guia? Como esperar que nela possa se instaurar uma relação justa? E que dizer da imagem que Homero e Hesíodo veiculam dos deuses?

É em meio a considerações dessa ordem que, em 365 B, o próprio Adimanto se interroga sobre o efeito desses discursos na alma de jovens mesmo dotados de boa índole. Sua intervenção conclui-se por uma bela citação de Píndaro (frag. 213) sobre a alternativa com que cada um é confrontado: "Subirei até a torre mais alta para lá me abrigar e passar minha vida pelo caminho da justiça ou do fingimento enganador?»

O desenvolvimento do diálogo entre Adimanto e Sócrates nos instrui sobremaneira a respeito das motivações que alimentam a desconfiança de Platão em relação aos poetas. Elas se situam decisivamente no campo da ética e da paideía. Não se trata de prender, em algum Goulag helênico, os grandes poetas da tradição, mortos há muito, ou mesmo os poetas trágicos mais recentes ou quase contemporâneos, como foi até sugerido por leitores apressados e ávidos por traçar uma genealogia para o totalistarismo do século XX, mas sim de destroná-los da posição que ocupam e da autoridade que gozam no âmbito da educação. Esta é a condição para se dispensar aos jovens uma formação inseparavelmente voltada para o transcendente e para $o$ bem da pólis.

Daí a proposição que faz em seguida Sócrates a Glauco e a Adimanto de examinarem a questão da justiça. Isso não significa que estejam prestes a abandonar as considerações sobre a poesia e as artes, tanto mais que numa cidade complexa como a pólis ateniense o papel das artes é da maior importância. A educação dos guardiães deve repousar sobre a ginástica e a mousiké, a arte das musas, embora a mais alta mousiké seja justamente a arte do filósofo. Em torno da noção de imitação, cujo papel é essencial quando se cogita de arte, surge então no diálogo a oposição entre alethés e pseûdos. 
Uma simples tradução desses termos por 'verdadeiro' e 'falso' não é suficiente para compreendê-los, como já sublinhara Heidegger ${ }^{21}$. Importanos em particular esclarecer o sentido de pseûdos e para isso não é inútil nos voltarmos para o uso que fazem nossas línguas do grego pseûdos como prefixo. Consultando o dicionário francês Robert encontrei uma ilustração que ajuda a pensar sobre as nuances do termo. O exemplo proposto é o de pseudo-membrana, cuja definição é "uma produção patológica inflamatória na superfície de uma mucosa e que se assemelha a uma membrana e é formada pela acumulação de fibrinas".

O interessante nesta definição é ela não comportar a palavra "falso", mas evocar as noções de produção, de semelhança e fazer referência ao material de formação. A pseudo-membrana não deixa de ser algo que produz seus efeitos. Isto parece se coadunar com certos empregos de "pseudos" em relação à questão da imagem. Além do mais, quando, para surpresa de todos, Sócrates diz que a educação dos guardiães deve começar pelo "pseudos", que quer ele dizer com isso? Ele próprio responde a Adimanto: "Você não sabe que se começa a educação das crianças lhes contando histórias, fábulas (mûthoi)?" (Resp. $377 \mathrm{~A})$.

O problema não é que as estórias destinadas às crianças sejam ficcionais, que é aqui o sentido que está sendo dado a "pseudos", mas sim o fato que nem todas as estórias são boas para serem contadas às crianças. Muitas são feias, pois "representam os deuses e os heróis de maneira errônea..." (Resp. $377 \mathrm{E})$.

Há portanto ficções boas e outras más. Feias ou más seriam aquelas cujo efeito na educação é pernicioso, induzindo a uma visão falsa das ações a serem imitadas. É assim que não se pode pintar o Deus —note-se o singular em 380 B-C - como se fosse o autor dos males que se abatem sobre os homens. Temos aí um dos traços determinantes do que se poderia chamar de teologia platônica, contraposta à dos poetas. Deus não pode ser autor do mal.

O que Platão critica nas fábulas dos poetas não é de modo algum que sejam mûthoi, mas que não sejam belas porquanto induzem a uma falsa idéia do divino e do que é justo. A esta altura não somente o divino Homero é criticado mas até mesmo o caro Ésquilo quando declara que "Deus implanta o crime no coração dos homens quando quer arruinar completamente suas casas" (frag. 160].

Tríplice é o defeito, ou o dano, de tais declarações: são ímpias, não têm utilidade e, além do mais, são incompatíveis entre si. Outro pomo de discórdia com os poetas são as metamorfoses que imputam aos deuses. Apresentam 
os deuses travestidos, enganando os homens, como se fossem fantasmas de si mesmos. Segundo Sócrates, isso tudo é inverossímil, pois "um deus não pode mentir nem em palavra nem em ação". Sabe-se o quanto essa conjunção entre palavra e ação era essencial para o êthos grego no que tinha de mais elevado. Também Sófocles a põe em relevo, como o vemos em particular no Filoctetes em torno da figura de Ulisses ${ }^{22}$. Platão sempre a isso retorna, pois a dissociação entre palavra e ação era aquilo mesmo que caracterizava o ensino de grande parte dos sofistas, o que comprometia a justiça que devia reinar na pólis.

Voltemo-nos mais um pouco para o problema da metamorfose dos deuses. Há metamorfose e metamorfose. Muitos contos apresentam um ensino moral por meio de uma mudança na aparência dos personagens, o que à primeira vista engana, mas que, por isso mesmo, exige um esforço interior, espiritual, de reconhecimento. Foi o que reteve a atenção de Simone Weil. Na coletânea póstuma intitulada Intuitions pré-chrétiennes, ela reproduz um conto escocês, O Duque da Noruega, e dele faz um comentário do qual permito-me citar um trecho significativo:

“A aparência miserável da princesa, sua admissão no palácio como auxiliar de cozinha indica que Deus vem a nós completamente despojado não somente de seu poderio, mas também de sua glória. Vem a nós escondido e a salvação consiste em reconhecê-lo" ${ }^{23}$.

Presente também na maioria das tragédias, o tema do reconhecimento foi meditado por Simone Weil com grande acuidade espiritual. Ela tinha uma predileção pela cena da Electra de Sófocles onde, de início, a heroína não reconhece o irmão Orestes. Ao explicitar o que se dá em tais ocasiões, escreve: "Crê-se ter diante de si um estrangeiro e é o ser mais amado", acrescentando adiante: "Foi também o que ocorreu no caso de Maria Madalena e de um certo jardineiro" (p. 16).

Com essa digressão em companhia de Simone Weil, estou procurando dizer que nem toda metamorfose é repreensível. Pode ser um meio de ultrapassar as aparências e de fazer descobrir uma realidade superior em relação ao divino. Todavia, quando Sócrates adverte o poeta insistindo para que "não venha nos representar os deuses com os traços de viajantes estrangeiros percorrendo as cidades com travestimentos de toda a espécie" (Resp. $381 \mathrm{D})$, tem em vista um contexto narrativo onde os deuses se transformam com o

22 Ver meu artigo «L'enjeu des voix dans le Philoctète de Sophocle», Études Philosophiques (juillet-septembre 1991).

23 WEIL, Simone, Intuitions Pré-chrétiennes, Fayard, Paris 1985, p. 14. 
fito de cometer ações vis, enganando os homens. É sobre essa reprentação dos deuses que recai sua crítica.

Passemos agora ao Livro III, onde o que se questiona não é mais a representação dos deuses mas a dos heróis que em princípio deveriam servir de modelo para os guardiães, dos quais se espera que sejam corajosos e capazes de sacrificar a própria vida pela cidade. Para preencher tal objetivo seria preciso coibir os discursos suscetíveis de fazer temer a morte e preferir a derrota e a escravidão. O diálogo envereda então por aquelas representações dos poetas que dão uma imagem terrível da mansão dos mortos. São reveladoras, aliás, das crenças sobre o que nos aguarda depois da morte. Dentre as várias afirmações que constam do florilégio reunido por Platão, encontramos os versos 103-104 do Canto XXIII da Ilíada:

"Grandes deuses! ainda há de nós na mansão dos mortos uma alma (psukhé) e uma sombra (eídolon), mas ela não tem sentimento algum".

O termo traduzido aqui por 'sombra' é eídolon, que se costuma traduzir por 'imagem'. É recorrente em Platão. No Sofista adquire um sentido mais genérico, pois se trata então de distinguir entre duas espécies de imitação : a que produz o phántasma e a que produz uma imagem verdadeira, eikón. Mas eidolon pode se opor a eikón. Daí 'ídolo' e 'ícone'. Nos versos de Homero que acabamos de citar, eídolon é o que subsiste do morto, o seu fantasma ou sua sombra, uma vez que sua alma não tem mais vida e é portanto desprovida de sentimento. Porém a tradução por sombra deixa bastante a desejar, já que nos versos seguintes aparece o termo skiaí, plural de skiá (sombra). Foi aliás sobre skia que se construiu o termo de skiagraphía, para designar a pintura que cria por meio de sombras a ilusão de uma certa profundidade e que portanto é enganosa por nos fazer tomar a imagem, o fantasma pela realidade ${ }^{24}$.

Esse desdobramento do diálogo nos leva a ver que a censura de alguns versos ou passagens dos poemas homéricos incide sobre o que neles é afirmado e portanto coloca em questão o pensamento (diánoia )que lhes é subjacente e que enganam aqueles que pretendem por ele pautar suas crenças e ações. Não é a vertente poética dos poemas que está em causa, apesar de Sócrates sugerir em 287B que quanto mais eles forem poéticos tanto menos devem ser ouvidos por homens que se destinam a viver como homens livres, isso porque o que é expresso poeticamente é mais fácil de ser memorizado e

24 O emprego desse vocabulário (homérico), que fazia agora parte também do vocabulário da pintura, é freqüente no Livro IX da República. Temos, por exemplo, algumas ocorrências de eídolon com o sentido de 'fantasma' em 586B-C (Helénes eídolon), 587C. Nas mesmas passagens, encontramos ainda skia, ou melhor, vários de seus derivados. (Cf. 583B, 585B). 
goza de um maior poder de persuasão. Em outras palavras, graças "à medida, ao ritmo e à harmonia" 25 o poeta confere às histórias transmitidas uma promoção poética que as torna ainda mais persuasivas e eficazes.

O exame seguinte volta-se para as representações que mostram os heróis chorando, se lamentando ou ainda se conduzindo com avidez, intemperança e manifestando portanto uma ausência de autocontrole e de harmonia interior. Daí chega-se à alternativa, expressa em 391E, segundo a qual os heróis, tidos por semi-deuses, ou não cometeram os atos que lhes são imputados pelos poetas ou não foram engendrados por deuses de acordo com a genealogia lendária comumente admitida. Impossível seria manter as duas afirmações por serem incompatíveis entre si. Na base dessa crítica encontramos pressuposta uma das fortes exigências do lógos filosófico, a da coerência.

Dos heróis passa-se aos homens e ao que deles se diz. Trata-se então de se retirar aos poetas e aos fazedores de discursos em geral o direito a afirmações segundo as quais haveria justos infelizes ou mesmo fazendo acreditar que a injustiça, caso escondida, disfarçada, seria mais vantajosa que a justiça. Essa questão já tendo sido abordada no Livro II, Sócrates prefere considerar a distinção, situada no plano da expressão, da léxis, entre diégesis e mímesis, isto é, entre a narração simples, feita na terceira pessoa, e a narração mimética. Delineia-se aqui a desconfiança que vai pesar sobre a poesia mimética. Como se sabe, Sócrates acabará declarando, não sem uma boa dose de ironia, que é preciso conduzir o poeta mimético a uma outra cidade depois de lhe ter prestado todas as honras.

Isso, porém, não quer dizer que toda mímesis, toda imitação, seja por si própria condenada. É preciso conservar para os jovens a possibilidade de imitar aqueles heróis que se distinguem pela beleza de seu caráter e de sua conduta. Esboça-se a distinção que se delineará mais claramente nos diálogos ulteriores e, em particular no Sofista, entre uma boa mímesis e uma má mímesis ${ }^{26}$, embora o traço dominante da República, em contraste com o $\mathrm{Fe}$ dro, o Banquete e o Sofista, seja ainda uma grande desconfiança em relação à poesia e à arte mimética.

Sócrates traz ainda à baila o canto como modo próprio da enunciação poética. Notemos que inicialmente a palavra mélos (de onde vem melodia) não era empregada senão no plural — mélea - e queria dizer os membros do corpo considerados na sua articulação. Mélos é uma articulação de tons considerados em sua disposição global.

25 Cf. República X 601 A.

26 Cf. VILLELA-PETIT, Maria, «La question de l'image artistique dans le Sophiste», AUBENQUE, P., (sous la direction de) e NARCY, M. (textes recueillis par), Études sur le Sophiste, Bibliopolis, Napoli 1991. 
Em 398D, Sócrates declara que um mélos se compõe de três elementos: as palavras, a harmonia e o ritmo. Quanto às palavras (lógoi), o fato de serem ou não cantadas não altera seu sentido. Não há pois nada mais a acrescentar ao que já foi dito a esse respeito. É a harmonia e o ritmo que devem ser agora levados em conta do ponto de vista ético-pedagógico. Do mesmo modo que, quando foi abordada a representação dos heróis, Sócrates teve por bem interditar as lamentações (thrênoi) e as queixas (odurmoí), também aqui pretende eliminar dos cantos as harmonias melancólicas ou lascivas. Cita como exemplos de harmonias a serem rejeitadas, a fim de se evitar um enfraquecimento geral do caráter, a harmonia lídia mista ou aguda assim como a harmonia jônica. Importa que sejam preservadas as harmonias mais viris e também aquelas que encorajam a sabedoria e a moderação. Tais qualidades são inerentes às harmonias dórica e frígia evocadas por Glauco.

Dessa preferência em matéria de harmonia decorre ainda a escolha dos instrumentos a serem privilegiados. Dentre eles a lira, a cítara ou mesmo uma espécie de flauta de Pan, enquanto outras flautas devem ser preteridas. $\mathrm{Na}$ verdade constata-se aqui a preferência pelos instrumentos apolíneos em detrimento dos associados ao culto dionisíaco. Feitas essas recomendações no campo da harmonia, há que se considerar a questão do ritmo. Intimamente ligado ao sopro vital, o ritmo coloca o canto e a música em geral em relação com os movimentos corporais, como atesta o fato de que a unidade rítmica receba o nome de "pé". Glauco confessa que, embora saiba quais são as espécies de ritmo, ignora a correspondência de cada uma delas com o caráter, que é o que deve ser levado em conta na escolha dos ritmos a serem encorajados. Sócrates replica que sobre esse ponto eles consultarão Dámon para ficarem mais cientes de quais as medidas rítmicas associadas à baixeza, à violência, ao desregramento e quais as inerentes às qualidades opostas (400B). Em tudo isso, acrescenta Platão, a excelência decorre da simplicidade da alma, que não é a simplicidade dos tolos mas daqueles cujo caráter alia bondade e beleza.

O que já nos faz ver esse desenvolvimento em torno da poesia nos primeiros livros do diálogo é a unidade profunda que abraça todos os aspectos da vida e como, na busca da sabedoria, cada um deve tender a se unificar. Notável é também por nos mostrar um filósofo levando em conta todos os aspectos das artes e não apenas aqueles que têm a ver com as significações expressas pela linguagem. Por outro lado, o diálogo assume a relevância da arte para a vida e o seu efeito sobre a alma. A arte (o que chamamos de "arte") pode ou não contribuir para a conquista da harmonia que segundo Platão caracteriza a alma justa. 


\section{A “expulsão dos poetas” e o necessário recurso ao mito no Livro X}

É somente levando-se em conta esse horizonte de considerações que se pode proceder a uma leitura do Livro X, não o tomando, sem mais, ao pé da letra. Antes de abordá-lo, seria conveniente recordar as inúmeras referências à poesia e às artes em geral que comportam os livros centrais do diálogo. Como esquecer o papel privilegiado da música na educação? É, no entanto, à pintura que recorre Platão ao forjar suas comparações, como é o caso quando Sócrates replica à objeção de Adimanto segundo a qual os guardiães podem não se sentir felizes com as interdições que lhe são feitas (somente a eles e não a todos, note-se). Ao declarar que o que deve primar na cidade é a felicidade do todo e não a de cada uma de suas partes, Sócrates se serve da comparação com a pintura de uma estátua. Não há por que reservar as mais belas cores às mais belas partes do corpo - teríamos então o olho pintado de vermelho-; o que importa é a beleza e a perfeição do todo. (A questão que caberia levantar aqui é uma das mais essenciais em filosofia moral: qual a relação entre o singular, o universal e o todo?)

No Livro VI temos uma comparação magnífica entre o pintor e o filósofo, pois aí, em 500E, o filósofo é dito ser como um pintor fazendo sua obra com os olhos voltados para um modelo divino. Esta comparação vem logo depois de uma interpelação de Sócrates a Adimanto: "Acredita você que, quando se vive com aquilo que se admira, seja possível não imitá-lo?”. O verbo mimeîsthai, 'imitar', é aqui empregado de maneira totalmente positiva.

Ora, essas nuances parecem desaparecer no Livro X. Foi baseando-se nessa diferença que Julia Annas em seu livro sobre a República ${ }^{27}$ sugere que com o Livro IX se encerra a argumentação do diálogo e que o Livro X teria sido redigido anteriormente e não passaria de um adendo bem inferior ao que precede. Ela divide o Livro $\mathrm{X}$ em duas partes: a primeira relativa à "expulsão da poesia" (595A-608C) ; a segunda (608C-621D) seria uma espécie de fourre-tout onde se retoma o tema das recompensas da justiça. Creio que Julia Annas simplifica demais as coisas sobretudo por não conceder a atenção devida ao mito de Er, que termina o diálogo. O que se precisa compreender são as razões de Platão para manter o Livro X como fecho da República.

Na passagem onde se lê que a poesia mimética deve ser expulsa da cidade, a cidade de que metaforicamente se trata é antes de mais nada a da nossa própria alma. Para que ela seja bem governada, convém liberá-la das crenças e dos apegos incompatíveis com a justiça. Platão está sendo irônico quando 
inverte os termos da denúncia da qual foi vítima seu mestre: "vocês não vão me denunciar aos poetas trágicos e aos outros artistas que praticam a imitação".

Além disso, o efeito negativo da poesia mimética só parece atingir aqueles que não têm um antídoto, que ainda não estão imunizados contra as aparências. Não se pode também excluir que Platão seja crítico em relação sobretudo a Eurípides pelos excessos de seu teatro. E se dele remonta até Homero, que é o poeta dos poetas e tido por pai dos trágicos, não o faz antes de lhe prestar uma bela e enfática homenagem, confessando a ternura e a admiração que por ele nutria desde de sua mais tenra infância (595B 9$595 C$ 3). Só que o amor à poesia não deve impedir o filósofo de ser lúcido ${ }^{28}$ e de banir de sua alma aquilo que no pensamento de Homero e dos outros poetas fica muito aquém da verdade ou mesmo a deforma, como é o caso da imagem que os poemas de Homero, de Hesíodo e dos trágicos propõem dos deuses.

Ao poeta dos poetas e aos seus herdeiros falta aquilo que cabe ao filósofo instaurar e que, com o filósofo francês Jean Nabert, poderíamos chamar de "criteriologia do divino" 29 . Para Nabert é a idéia do divino (imanente ao nossso espírito) e a evidência do testemunho que dele se dá, que permite julgar se é deveras divino aquele que está sendo invocado como deus. Â luz dessa observação, que leva a concluir que os deuses dos poetas ficavam freqüentemente aquém da idéia do divino, examinemos a sugestão feita por Julia Annas de que o Livro IX poderia muito bem encerrar o diálogo.

Tivesse Platão tomado tal decisão, não apresentaria o diálogo algo de inacabado e de inconseqüente? Havendo começado pelo exame de afirmações poéticas, verdadeiros lugares-comuns do discurso vigente em sua época, Platão teve por bem considerar os ensinamentos dos poetas, suas "sentenças", suas afirmações no que tinham de insatisfatório para a formação da alma. Sua volta ao caso dos poetas (ou à sua causa) se revela essencial, do mesmo modo que a volta à caverna na alegoria do mesmo nome. Reitera-se assim o esquema de saída da caverna e do necessário retorno a ela, com a obrigação de instruir os que lá estão. Vai daí o recurso final ao mûthos, do qual o lógos se distingue, mas que ao mesmo tempo ele requer. Platão, o filósofo, não hesita asssim a se apresentar como um filómito ${ }^{30}$, ou mesmo um muthopoiós, quando isso se faz necessário. tion de), Philosophie, Poésie, Mystique, coll. Institut Catholique de Paris 18, Beauchesne 1999.

29 Cf. NABERT, Jean, Le Désir de Dieu, Préface de Paul Ricoeur, Cerf, Paris 1996.

30 Cf. REY PUENTE, Fernando, «O philómuthos e o philósophos», Kritérion 102 (2000), p. 128-135. 
E se o diálogo se encerra pelo mito de Er, não seria pelo fato de que o mito permite oferecer uma narração simples, diegética, e não mimética, ao mesmo tempo cheia ensinamentos e não eivada de afirmações contraproducentes como as encontradas na narração mimética dos trágicos?

O lugar ocupado pelo mito ao fim do diálogo confirmaria então a hipótese que é a compreensão do divino e de sua relação com a felicidade ou infelicidade dos homens que está em jogo e que justifica o afastamento dos poetas do seu papel de educadores da cidade e de sua juventude. Em suma, se as palavras dos poetas devem ser banidas, isso decorre da visão distorcida que elas oferecem do que é bom e justo para a alma e para a cidade.

Num capítulo intitulado "O Deus mau e a visão trágica da existência" de um livro já antigo de Paul Ricœur, La Symbolique du Mal, onde a crítica de Platão aos poetas não é esquecida, encontramos uma reflexão deveras esclarecedora do que está aqui em jogo:

“É na tragédia grega que o tema do homem tornado cego e conduzido à sua perda pelos deuses atingiu de uma só vez o extremo de sua virulência, de tal maneira que todas as imitações do trágico grego talvez não sejam mais que expressões atenuadas dessa mesma revelação insuportável" ${ }^{\text {31 }}$.

Ora, é aos olhos do filósofo que essa revelação do divino se manifesta como insuportável ou melhor como exigindo ser ultrapassada. Ela o é, em todo caso, para um pensamento que exclui todo mal do divino por assimilálo ao Bem ou ao absoluto do Amor.

Isso não impede porém, como também o sublinha Paul Ricœur, que o filósofo veja na representação trágica um convite "a tentar uma hermenêutica do símbolo trágico". Num parágrafo, cujo título é uma interrogação "Délivrance du tragique ou délivrance dans le tragique?", ele evoca a Orestéia de Ésquilo. As três peças que compõem a trilogia —Agamemnon, As Coéforas e as Eumênides - constituem uma progressão que leva da divindade malévola, cuja contrapartida é a cegueira do homem, à divindade benévola que, em última análise, converge com a afirmação da responsabilidade humana.

Ricœur destaca ainda Édipo em Colono, onde Sófocles trata do fim da vida do herói tebano. Nesta peça os deuses aparecem primeiro como injustos, protegendo os homens vis, até se manifestarem de modo inverso aos olhos do herói sofredor, que pode então morrer em paz. A tragédia se conclui por um hino de reconhecimento a Zeus.

Em outras palavras, a concepção de um Deus mau dar-se-ia como pólo 
intencional de uma visão deturpada, a do homem tornado cego por sua própria injustiça ou por um excesso de infelicidade. Dizendo isso estou, é claro, defendendo a dimensão ética da tragédia. Não há como negar que Ésquilo e Sófocles contribuíram grandemente para promover uma visão menos rudimentar do divino. Estaria eu por minha vez agravando o caso de Platão em sua condenação da tragédia? Acredito que não. O que ele denunciou foi a ambivalência relativa ao divino que subsistia nos trágicos e sobretudo o uso que faziam dos poetas tanto a opinião comum quanto os sofistas.

Se Platão preconizava uma regulação do uso da produção poética como hoje são chamados a fazer os comitês de ética em relação às produções tecnico-científicas ou às produções da mídia no setor da comunicação-, não instituía um tribunal para condenar desvios relativos a uma ortodoxia, a um corpo de definições dogmáticas, como aquele que condenara seu mestre Sócrates. O que ele queria traçar eram as coordenadas de uma educação capaz de implantar na alma uma harmonia e uma aspiração ao Belo e ao Bom.

A pergunta crucial a ser endereçada ao Livro X da República seria então a seguinte: será que a educação pode ser feita a partir somente de bons exemplos, quando inevitavelmente em nosssa experiência da realidade confrontamos toda espécie de conduta? Platão parece não ter podido entrever os efeitos, muito diversos, que produzem as fábulas sobre a alma de cada um. Nem tampouco foi de todo capaz de avaliar o que a alma humana comporta de meandros, de desvios e de inclinações perversas. Donde sua confiança na educação. Talvez não tivesse como vislumbrar a profundidade do mal, da húbris que nos ameaça e, portanto, o que as nossas ações podem ter de injustificável já que em cada alma tende a prevalecer o amor injusto ou ilusório de cada um por si mesmo ou pelos seus, mesmo ao preço do bem devido aos outros.

O trágico resiste assim à filosofia, ao amor do filósofo pela sabedoria, porque corresponde à experiência, por um lado, da húbris, por outro, da infelicidade que pode se abater sobre o ser humano, mesmo inocente. Esta última é que faz brotar do peito o grito ou o murmúrio: "Por quê? Por que tal coisa me acontece?". Também no livro de Job encontramos um equivalente dessa interrogação, que atinge seu clímax no "Por que me abandonaste?" da Cruz.

Em outras palavras, a tragédia enfrenta o enigma, ou melhor, o mistério da existência que a busca da sabedoria pelo filósofo não consegue de todo eliminar. Daí sua contribuição para o auto-conhecimento do homem e seu poder terapêutico, como o reconheceu Aristóteles. Só que quando o autor da Poética nela aborda a tragédia, não o faz em termos dialéticos. Não está aí, como Platão na República, à procura de uma melhor definição do "justo".

Em resumo, o que se pode dizer é que se a poesia mimética oferece um 
espelho majestoso da condição humana, nem por isso dispensa o filósofo de clarificar e retificar a diánoia dos poemas, com vistas às noções que norteiam e, de certo modo, moldam a existência dos homens, a começar pelas idéias que se fazem do divino. Foi o que Platão, o discípulo de Sócrates, tão bem compreendeu ${ }^{32}$.

32 Nota Bene: Não foram abordadas, neste artigo, dois dos principais temas relativos à questão da poesia em Platão: o que se refere à inspiração e o que concerne à distância da mímesis poética à verdade. $\mathrm{O}$ primeiro só poder ser tratado com base em outros diálogos (íon, Fedro, Banquete), e não na República. Quanto ao segundo, que remete a uma comparação, estabelecida justamente nesse diálogo, entre a mímesis artesanal e a mímesis artística, ele tem a ver não somente com a poesia, mas com a mímesis artística enquanto tal. Tema cuja interpretação requer também o concurso de outros diálogos e que estudamos alhures com relação ao Sofista (nota 26). Gostaria ainda de deixar bem claro que não pertenço à área acadêmica da Filosofia Antiga. Afora a admiração que, como filósofa, tenho naturalmente por Platão, minhas incursões no domínio grego foram muitas vezes ditadas pelo meu ensino de Estética no Institut Catholique de Paris, onde tive ocasião de dar cursos sobre «Filosofia e Poesia», «Poesia e Pintura» ou «Arte e Verdade». As considerações desenvolvidas neste artigo são em parte oriundas de um curso sobre «Filosofia e Poesia», onde, indo de Platão a Heidegger, procurei pensar as variações, ao longo da história, das atitudes filosóficas em relação à poesia. 